\title{
Adventive hydrothermal circulation on Stromboli volcano (Aeolian Islands, Italy) revealed by geophysical and geochemical approaches: Implications for general fluid flow models on volcanoes
}

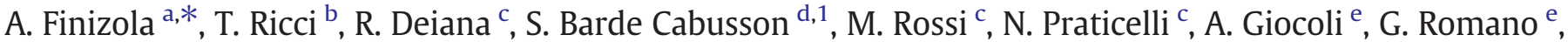 \\ E. Delcher ${ }^{\text {b }}$, B. Suski ${ }^{\text {}}$, A. Revil ${ }^{\text {g,h }}$, P. Menny ${ }^{i}$, F. Di Gangi ${ }^{j}$, J. Letort ${ }^{k}$, A. Peltier ${ }^{l}$, V. Villasante-Marcos ${ }^{\mathrm{m}}$, \\ G. Douillet ${ }^{\mathrm{k}}, \mathrm{G}$. Avard ${ }^{\mathrm{n}}$, M. Lelli ${ }^{\mathrm{o}}$ \\ a Laboratoire GéoSciences Réunion, UR, IPGP, UMR 7154, Saint Denis, La Réunion, France \\ b Istituto Nazionale di Geofisica e Vulcanologia, Roma, Italy \\ c Dipartimento di Geoscienze, Università degli Studi di Padova, Padova, Italy \\ d Dipartimento di Scienze della Terra, Università di Firenze, Firenze, Italy \\ e Laboratorio di Geofisica, IMAA-CNR, Tito Scalo, Potenza, Italy \\ $\mathrm{f}$ Institut de Géophysique, Université de Lausanne, Lausanne, Switzerland \\ $\mathrm{g}$ Colorado School of Mines, Illinois St. Golden, Colorado, USA \\ h CNRS-LGIT, UMR 5559, Université de Savoie, Equipe Volcan, Le Bourget du Lac, France \\ i Laboratoire Magmas et Volcans, Université Blaise Pascal, Clermont-Ferrand, France

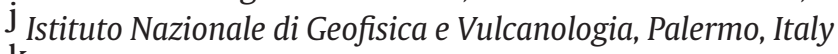 \\ $\mathrm{k}$ Ecole et Observatoire des Sciences de la Terre, Université de Strasbourg, France

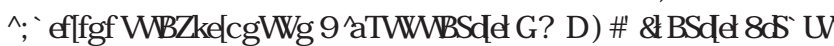

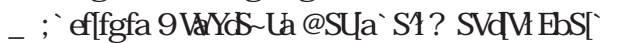

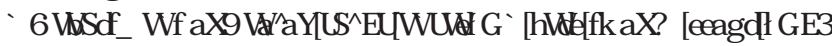

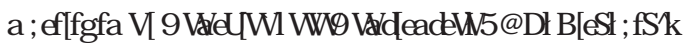

\section{A B S T R A C T}

On March 15th 2007 a paroxysmal explosion occurred at the Stromboli volcano. This event generated a large amount of products, mostly lithic blocks, some of which impacted the ground as far as down to $200 \mathrm{~m}$ a.s.l., about $1.5 \mathrm{~km}$ far away from the active vents. Two days after the explosion, a new vapour emission was discovered on the north-eastern flank of the volcanic edifice, at $560 \mathrm{~m}$ a.s.l., just above the area called "Nel Cannestrà". This new vapour emission was due to a block impact. In order to investigate the block impact area to understand the appearance of the vapour emission, we conducted on May 2008 a multidisciplinary study involving Electrical Resistivity Tomography (ERT), Ground Penetrating Radar (GPR), Self-Potential (SP), $\mathrm{CO}_{2}$ soil diffuse degassing and soil temperature surveys. This complementary data set revealed the presence of an anomalous conductive body, probably related to a shallow hydrothermal level, at about 10-15 m depth, more or less parallel to the topography. It is the first time that such a hydrothermal fluid flow, with a temperature close to the water boiling point $\left(76^{\circ} \mathrm{C}\right)$ has been evidenced at Stromboli at this low elevation on the flank of the edifice. The ERT results suggest a possible link between (1) the main central hydrothermal system of Stromboli, located just above the plumbing system feeding the active vents, with a maximum of subsurface soil temperature close to $90{ }^{\circ} \mathrm{C}$ and limited by the NeoStromboli summit crater boundary and (2) the investigated area of Nel Cannestrà, at $\sim 500 \mathrm{~m}$ a.s.l., a buried eruptive fissure active $9 \mathrm{ka}$ ago. In parallel, SP and $\mathrm{CO}_{2}$ soil diffuse degassing measurements suggest in this sector at slightly lower elevation from the block impact crater a magmatic and hydrothermal fluid rising system along the $\mathrm{N} 41^{\circ}$ regional fault. A complementary ERT profile, on May 2009, carried out from the NeoStromboli crater boundary down to the block impact crater displayed a flank fluid flow apparently connected to a deeper system. The concept of shallow hydrothermal level have been compared to similar ERT results recently obtained on Mount Etna and La Fossa cone of Vulcano. This information needs to be taken into account in general fluid flow models on volcanoes. In particular, peripheral thermal waters (as those bordering the northeastern coast of Stromboli) could be contaminated by hydrothermal and magmatic fluids coming from regional faults but also from the summit.

\footnotetext{
* Corresponding author.

E-mail address: anthony.finizola@univ-reunion.fr (A. Finizola).

Present address: Instituto de Ciencias de la Tierra Jaume Almera, CSIC Barcelona, Spain.
} 


\section{Introduction}

Stromboli volcano is located in the northern part of the Aeolian archipelago in the Tyrrhenian Sea. During the last millennium, Stromboli has been characterized by a permanent mild explosive activity (Rosi et al., 2000) sometimes interrupted by paroxysmal events producing ballistics that damaged also the inhabited lower part of the island. Since 1900, seventeen paroxysmal events have been evidenced. Fifteen paroxysms were recorded between 1906 and 1954 (Barberi et al., 1993). The two last paroxysms occurred on April 5th 2003 (Bonaccorso et al., 2003; Calvari et al., 2005; Calvari et al., 2006) and March 15th 2007 (Patanè et al., 2007; Carapezza et al., 2008; Neri and Lanzafame, 2008; Barberi et al., 2009; Rizzo et al., 2009). During the last event on March 15th 2007, several blocks of metric size impacted also the flanks of the volcano at an elevation of $\sim 500 \mathrm{~m}$ a.s.l. The impact of one of those blocks, located at an elevation of $560 \mathrm{~m}$ a.s.l., just above the northern part of the island called "Nel Cannestrà", triggered a new vapour emission zone, which was first observed on March 17th 2007 (Fig. 1a). In the same area is located the Nel Cannestrà eruptive fissure active 9 ka ago (S. Calvari, pers. comm.), and aligned with the $\mathrm{N} 41^{\circ}$ regional fault (Fig. 1b) of several tens of km long crossing the Aeolian archipelago. This sector is also a preferential $\mathrm{CO}_{2}$ degassing area where a permanent $\mathrm{CO}_{2}$ flux monitoring station has been installed in 2007 (Carapezza et al., 2008).

In the last decade, several geophysical and geochemical campaigns of measurements were carried out on Stromboli Island in order to delineate the hydrothermal circulation (Finizola et al., 2002, 2003; Revil et al., 2004; Finizola et al., 2006, 2009). At the scale of the Island, the lateral extension of the hydrothermal system of Stromboli seems to be well controlled by the NeoStromboli crater boundary ("NEO STR" in Fig. 1b) down to the investigated depth $\sim 215 \mathrm{~m}$ of the electrical resistivity tomographies performed to date (see Finizola et al., 2006).

During the last two eruptive crises of Stromboli (in 2002-2003 and in 2007), extensive surveys were performed to look for gas geochemical precursors before the onset of the eruption and the paroxysmal activity (Carapezza et al., 2004; Inguaggiato and Rizzo, 2004; Capasso et al., 2005; Carapezza et al., 2008; Rizzo et al., 2009). These surveys focused on different areas: the summit where the flux of $\mathrm{CO}_{2}$ from the soil was monitored, as well as Rina Grande (675 m a.s.l.) and Nel Cannestrà (525 $\mathrm{m}$ a.s.l.) areas, and along the north-eastern coast where dissolved gases $\left(\mathrm{CO}_{2}, \mathrm{H}_{2}\right.$, and $\left.\mathrm{He}\right)$ in thermal waters were analysed. For both eruptive crises, gas anomalies were clearly identified. It is interesting to note that precursors in the thermal waters (dissolved $\mathrm{CO}_{2}$ amount) appeared about five months before the 2002 eruption onset while high anomalous values of the flux of the $\mathrm{CO}_{2}$ were recorded at the crater rim only one week before the 2002 eruption onset (Carapezza et al., 2004). These results suggested that a direct magmatic gas contamination rose in the thermal waters located on the north-eastern coast of Stromboli. Such hypothesis is also supported by the He isotopic ratios of the thermal waters that were significantly higher (R/Ra closer to the magmatic end-member) than the summit fumaroles (Inguaggiato and Rizzo, 2004; Capasso et al., 2005; Rizzo et al., 2009). Dissolved gases in the thermal waters of Stromboli are now considered to be a good precursor for the ascent of magma.

In the present paper, we focus on area characterized by vapour emission first observed on March 17th 2007 and associated with a block impact crater. This active fluid flow area, of about $80 \mathrm{~m}^{2}$ (an

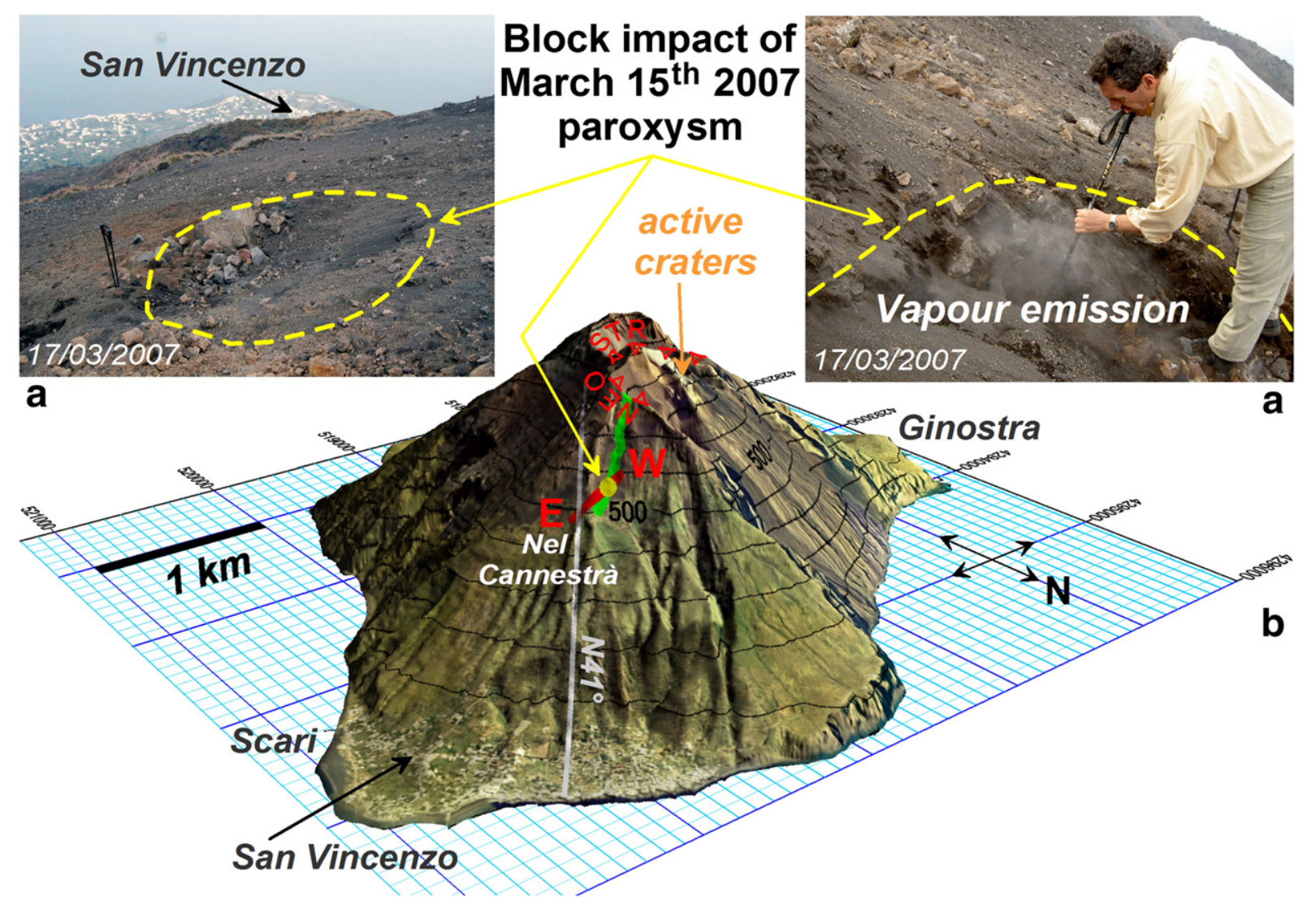

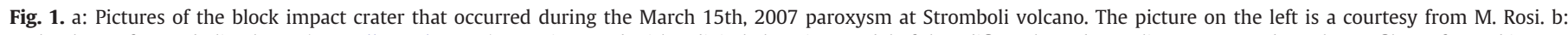

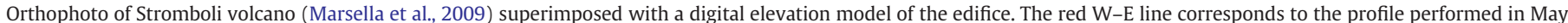

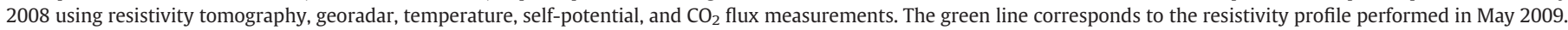

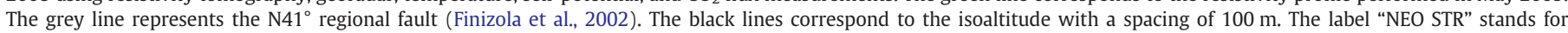
NeoStromboli crater boundary. The coordinates are in UTM(m)-WGS84. 
approximate circular zone of $10 \mathrm{~m}$ in diameter), is located at $560 \mathrm{~m}$ a. s.l. This area was investigated in May 2008 with several methods sensitive to the presence of ground water and/or fluid circulation. For this purpose, we used Electrical Resistivity Tomography (ERT), Ground Penetrating Radar (GPR), Self-Potential (SP), soil diffuse degassing $\left(\mathrm{CO}_{2}\right.$ flux), and soil temperature $(\mathrm{T})$ surveys.

\section{Field investigation methodologies}

In May 2008, we collected a set of geophysical and geochemical data along a W-E profile located between $590 \mathrm{~m}$ and $480 \mathrm{~m}$ a.s.l. and crossing the block impact crater associated with the March 15th, 2007 paroxysm (red profile in Fig. 1b). The measurements were georeferenced using a portable GPS navigation receiver and the elevation of each measured point was then extracted from a Digital Elevation Model (DEM).

Electrical Resistivity Tomography (ERT) measurements were obtained using a set of 64 steel electrodes spaced every $5 \mathrm{~m}$. The total length of the profile was therefore $315 \mathrm{~m}$ (see position in red in Fig. 1b). The electrode contact resistance was reduced by adding salty water. The Wenner-alpha array was used for its good signal-to-noise ratio. The apparent electrical resistivity data were inverted using the software RES2DINV developed by Loke and Barker (1996). The other measurements were performed only in the middle and upper parts of the ERT profile, along the first $240 \mathrm{~m}$, as the lower part of the profile encountered dense vegetation. In particular, temperature, selfpotential (SP), and $\mathrm{CO}_{2}$ flux measurements were performed with a regular spacing of $2.5 \mathrm{~m}$. In the vicinity of the impact area, the spacing between the measurements was reduced to $1 \mathrm{~m}$. For each of these three methods mentioned above, 111 measurements were collected.

Along the resistivity profile, we also collected one surface georadar (GPR) profile. GPR is a useful tool to determine fluid content at intermediate scale (down to a few tens of meters depending on the resistivity of the ground and therefore the attenuation to the electromagnetic waves) (e.g. Pettinelli et al., 2008). Furthermore, this method is effective in delineating major stratigraphic contacts in volcanic areas (Russell and Stasiuk, 1997; Gomez-Ortiz et al., 2006). The GPR profile was carried out using a GSSI SIR3000 system (Geophysical Survey System Inc.) equipped with a $40 \mathrm{MHz}$ monostatic antenna. The choice of the $40 \mathrm{MHz}$ antenna was representing the best compromise between penetration depth, resolution, and survey logistics. In our investigated area, the GPR data were collected in continuous mode moving the antenna close to the ground with a constant speed. Additional marks were made every $5 \mathrm{~m}$ to ensure normalization in data-processing. GPR measurements started at the origin of the ERT profile and stopped after $240 \mathrm{~m}$ in east direction. The SIR 3000 system was set with the automatic control of first reflector position, a gain control on 5 points, a vertical low-pass filter of $80 \mathrm{MHz}$, a vertical high-pass filter of $10 \mathrm{MHz}$, a scan-rate of 32 scans per second and a sampling rate of 512 samples per scan.

Ground temperature was measured with K-type thermal probes and a digital thermometer. Readings were taken to a precision of a tenth of a degree. Each temperature measurement was performed in four steps: (1) burrowing of a hole at a precise depth of $30 \pm 1 \mathrm{~cm}$ with a steel rod, $2 \mathrm{~cm}$ in diameter; (2) insertion of a thermal probe into the hole; (3) filling and compaction of the hole; (4) and temperature reading taken after $10-15 \mathrm{~min}$ to achieve thermal equilibrium. Previous studies performed on Stromboli (Finizola et al., 2003, Finizola et al., 2006) and Vulcano Islands (Revil et al., 2008; Barde Cabusson et al., 2009) showed that temperature measurements were a suitable method for determining the extent of hydrothermal activity close to the ground surface.

$\mathrm{CO}_{2}$ fluxes were acquired using the "accumulation chamber (AC) method" described by Chiodini et al. (1996), which is a passive geochemical technique for measuring $\mathrm{CO}_{2}$ diffuse degassing from the soil. $\mathrm{CO}_{2}$ soil diffuse degassing measurements were carried out by means of a portable diffuse flux meter developed by Westsystems srl and equipped with an IR spectrometer, an AC Type A (internal volume: $30 \mathrm{~cm}^{3}$ ) and a Pocket PC to visualise the data. The gas-air mixture within the AC is continuously analysed by the IR spectrometer while "concentration vs. time" curves are plotted on the PC. The method is based on the measurement of the $\mathrm{CO}_{2}$ concentration increasing inside the AC placed on the soil; the increase is directly proportional to the flux. $\mathrm{CO}_{2}$ anomalies have their origin mainly in magma degassing inside the volcanic system. The gas follows the same preferential pathways than the hydrothermal fluids providing information about high permeability pathways and the presence of a gas releasing source at depth.

Self-Potential (SP) measurements were carried out with a pair of non-polarizable $\mathrm{Cu} / \mathrm{CuSO}_{4}$ electrodes. The difference of electrical potential between the reference electrode (arbitrarily placed at the beginning of the profile) and the mobile electrode was measured with a high impedance voltmeter (sensitivity of $0.1 \mathrm{mV}$, internal impedance of $100 \mathrm{M} \Omega$ ). At each point, a $10 \mathrm{~cm}$ deep hole was dug to improve the electrical contact between the electrode and the ground. The main source of self-potential signal on volcanoes is generated by electrokinetic coupling (Corwin and Hoover, 1979). Indeed, the flow of ground water creates a macroscopic current density and an electrical field called the streaming potential, which is measurable at the ground surface (Revil et al., 1999a, b; Lorne et al., 1999a, b; Revil and Leroy, 2001). As a consequence, the streaming potential associated with the upflow of steam/liquid water in volcanic hydrothermal systems results in positive anomalies (e.g., Pribnow et al., 2003; Finizola et al., 2004; Revil et al., 2004).

Based on the first results obtained from the dataset of May 2008, another profile (green profile in Fig. 1b), only using ERT technique, has been performed in May 2009 to validate our hypothesis. This profile was carried out with the technical characteristics previously mentioned for ERT technique. It was oriented WSW-ENE, between $\sim 810$ and $500 \mathrm{~m}$ a.s.l., and covered a distance of $630 \mathrm{~m}$. This profile begins close to the NeoStromboli crater boundary, and its lower part crosses the block impact crater at a distance of $\sim 460 \mathrm{~m}$.

\section{Shallow hydrothermal circulations evidenced by field measurements}

Analyzing the results of both geochemical and geophysical measurements collected at Stromboli on May 2008, some interesting correspondences between various geochemical and geophysical data can be observed. First, the resistivity tomography (see Fig. 2) evidences a conductive body (resistivity comprised between from 20 to $150 \Omega \mathrm{m}$ ). This body lies to a maximum depth of $20 \mathrm{~m}$ and is comprised between two more resistive layers with a resistivity comprised between 150 and more than $1000 \Omega \mathrm{m}$. In Fig. 2, we can observed that the conductive body reaches the surface where it is correlated with a $\mathrm{CO}_{2}$ flux anomaly of $15980 \mathrm{~g} /\left(\mathrm{m}^{2} \mathrm{day}\right)$. This area coincides with the block impact crater, which is located at a distance of $80 \mathrm{~m}$ from the origin of the resistivity profile. This anomalous area is also characterized by a positive self-potential anomaly of $290 \mathrm{mV}$ and a temperature high of $76{ }^{\circ} \mathrm{C}$. The field observations of new vapour emissions inside the block impact crater of March 17th 2007 (Fig. 1a) are correlated with all the above anomalies in $\mathrm{CO}_{2}$, temperature, selfpotential and near surface resistivity. This led us to interpret the electrically conductive level as the manifestation of a hydrothermal fluid circulation. We infer that the impact of the volcanic block fractured the ground surface on and around the impact area allowing shallow hydrothermal fluids to move up to the surface through newly created high permeability fractures.

Fig. 2 shows the results of the GPR measurements. In this anomalous section, the region below the dashed black line exhibits a large attenuation of the electromagnetic waves. This is correlated with the electrically conductive zone in the resistivity profile. The 


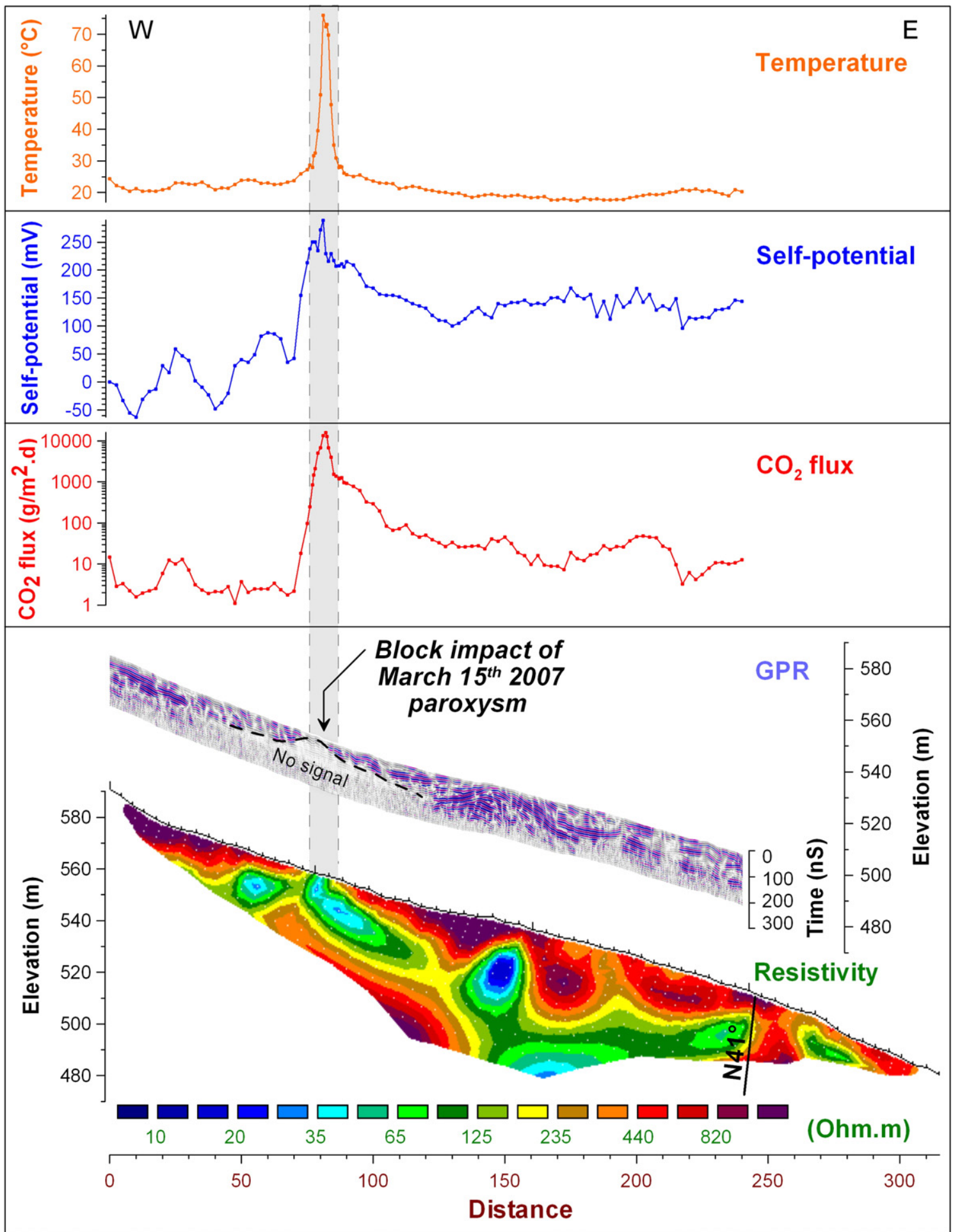

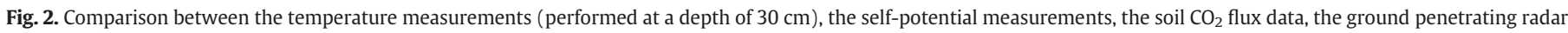

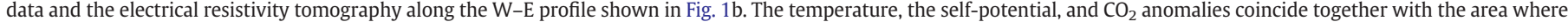
the electrical conductive body reaches locally the ground surface at the block impact point.

georadar data confirms the resistivity tomography results about the location and extension of the conductive body. Other variations in the intensity of the GPR signals can be associated in the ERT profile with the boundary between resistive and conductive bodies. At about $150 \mathrm{~m}$ of distance, the attenuation of the GPR signal evidences only the top of the ERT conductive body.

This thin shallow hydrothermal level identified at $~ 10-15$ m depth under the topography and more or less parallel to the topography suggests a drainage of hydrothermal fluids from the higher parts of the volcano, where the hydrothermal system reaches shallow depths (see Fig. 3 and Finizola et al., 2006). On our study area (at 560 $\mathrm{m}$ a.s.l.) and on this flank of the edifice, the first meters are exclusively constituted of fallout deposits coming from classical strombolian activity and paroxysmal explosions over more than a millennium (Rosi et al., 2000). A deep tephro-stratigraphic section of about $4 \mathrm{~m}$ was analysed by Rosi et al. (2000) in the same area. We could hypothesize a continuity of 
similar deposits up to the first tens meters below the ground surface and the associated hydrothermal fluid flow from the upper part to the lower part of the volcano. In order to confirm this hypothesis, we ran a second resistivity profile from the NeoStromboli crater boundary (at $\sim 810 \mathrm{~m}$ a.s.l) down to the block impact crater (see the green profile in Fig. 3) on May 2009. This profile identified the shallow conductive body along two thirds of the profile on two distinct areas; (1) in the upper part of the profile on $200 \mathrm{~m}$ long and (2) in the lower part of the profile on $\sim 150 \mathrm{~m}$ long crossing the block impact crater (respectively "SC2" and "SC1" in
Fig. 3). Between these two sectors, the shallow conductive body appears as a broken line. However, a careful analysis of the deep resistivity tomography profile performed along the Ginostra-Scari cross section (see Fig. 3 and Finizola et al., 2006), reveals a shallow conductive body located at a depth of $\sim 30-40$ m below the ground surface (see anomalies labelled "SC3" and "SC2" in Fig. 3). On the side of Ginostra, the depth of the shallow conductive level (SC3) decreases when going down along the flank of the volcano until it reaches the surface. On the side of Scari, the depth of the shallow conductive body (labelled SC2) increases going

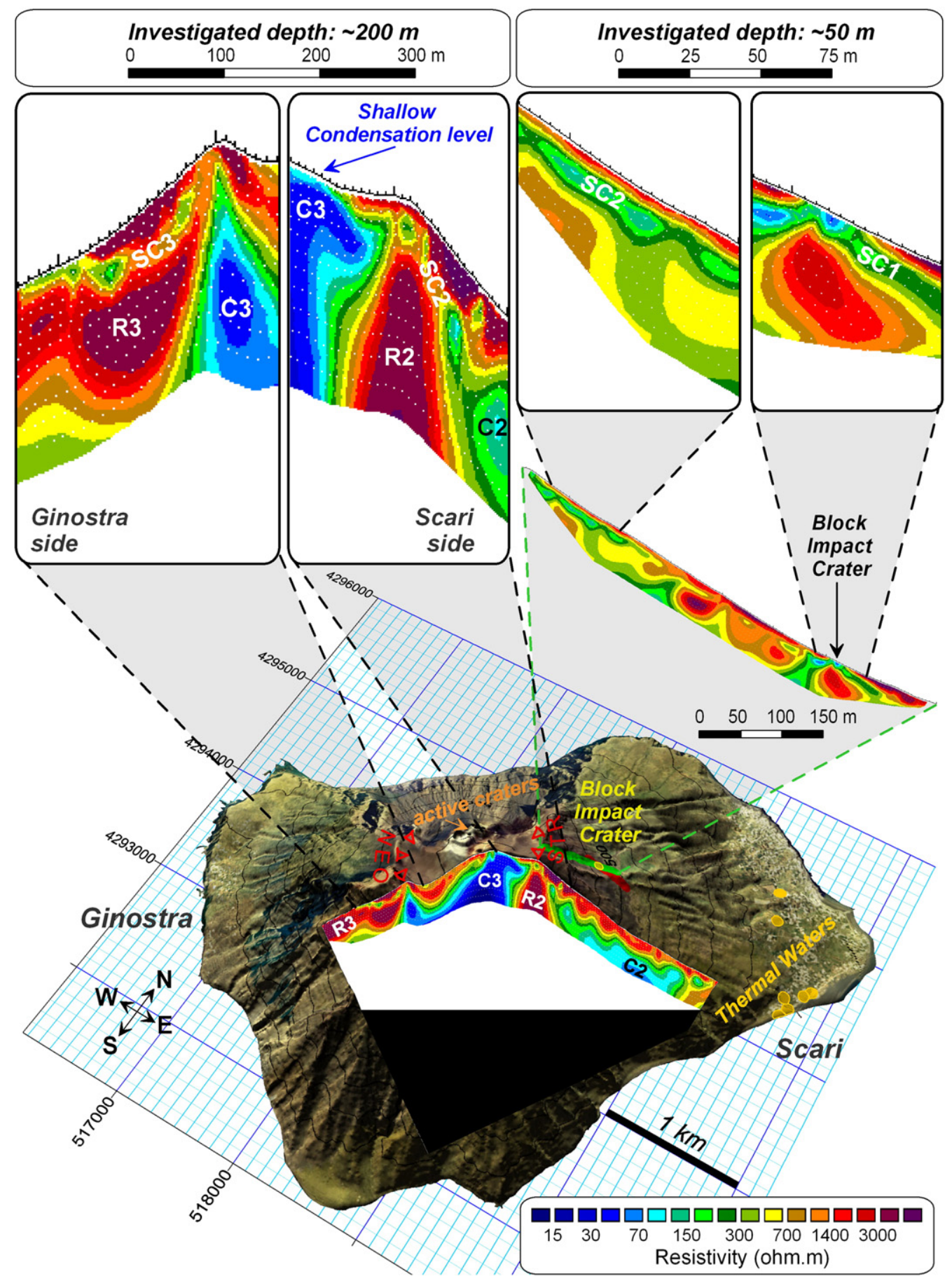

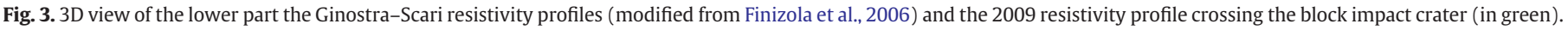

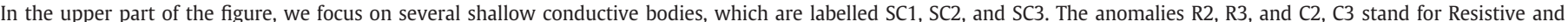

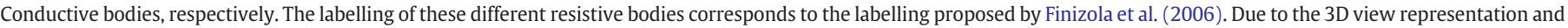

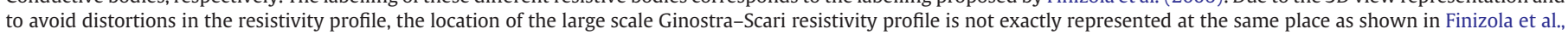
2006. The label "NEO STR" stands for the NeoStromboli crater boundary. 
down along the flank until it ultimately reaches the deeper "C2" conductive body. The comparison between the deep resistivity tomography profile and the shallow one (see Fig. 3) suggests that the shallow conductive body labelled "SC2" constitutes the same type of geological feature on both profiles. The anomalous body SC2 is clearly connected to the central (C3) hydrothermal system and could be a shallow outflow of the hydrothermal body. On the flank of the edifice, this outflow goes down through two possible ways (see Fig. 4): (1) a shallow one at a constant depth of $\sim 10-15 \mathrm{~m}$ or (2) a deeper one connected with the thick body C2 identified on the Ginostra-Scari profile (see Finizola et al., 2006). Few hundred meters downslope, in the vicinity of the block impact crater, these two sources seems to contribute to feeding the shallow outflow SC1 responsible for the fumarolic area observed just after the March 15th, 2007, paroxysmal explosion. According to the detailed resistivity profiles, a major contribution to this shallow fluid flow SC1 seems to come from the $\mathrm{C} 2$ conductive body. Nevertheless, a third major fluid contribution can be proposed for the vapour emission observed in the studied area. As described in the introduction chapter, the E-W electrical resistivity tomography profile crosses the regional $\mathrm{N} 41^{\circ}$ fault system (Carapezza and Federico, 2000; Finizola et al., 2002), at about $245 \mathrm{~m}$ of distance. Fig. 2 displays peculiar characteristics in $\mathrm{SP}$ and $\mathrm{CO}_{2}$ flux signal on both sides of the block impact crater; The eastern side of the profile (greater than $90 \mathrm{~m}$ in distance) shows higher level of anomaly (order of magnitude) from the western side (lower than $80 \mathrm{~m}$ in distance). This particularity can be explained if rising hydrothermal fluids $\left(\mathrm{CO}_{2}\right.$ and water vapour) are channelled along the $\mathrm{N} 41^{\circ}$ regional fault. Part of these fluids migrates toward the surface between $\mathrm{N} 41^{\circ}$ fault and the block impact crater. Moreover, the block impact crater constitutes a preferential recall of fluids. Therefore, water vapour and $\mathrm{CO}_{2}$ degassing dramatically decrease in the western part of the block impact crater (see Figs. 2 and 4). Between $245 \mathrm{~m}$ and $90 \mathrm{~m}$ of distance, higher amount of $\mathrm{CO}_{2}$ can reach the surface. So, the $\mathrm{N} 41^{\circ}$ regional fault seems to constitute a preferential hydrothermal path for the vapour emission related to the block impact crater. Moreover, due to the fact that the background of the signal is higher for self-potential and $\mathrm{CO}_{2}$ but not in temperature, this implies between the conductor and the surface an impermeable layer for water but permeable for $\mathrm{CO}_{2}$.

Based on the results of shallow hydrothermal fluid flow level deduced in this work on Stromboli volcano, we looked for similar studies obtained with the same ERT technique on other volcanoes. On
Mount Etna, a N-S ERT profile have been performed by Siniscalchi et al., 2010, crossing the Pernicana fault system constituting the northern boundary between the spreading and stable areas on the edifice. The ERT profile displays a conductive body (red-orangeyellow colours in Fig. 5a) at depth and reaching the surface in correspondence with the Pernicana fault system. In the northern part of the profile, a shallow conductive layer slightly deepening to the North has been evidenced. Similar results have been also observed on the eastern flank of La Fossa of Vulcano edifice (Revil et al., 2008; Barde Cabusson et al., 2009), where a conductive body confined inside the Pietre Cotte crater rim reaches the surface and extends toward the East with a shallow conductive layer parallel to the topography. In both cases (Etna and Vulcano), we can hypothesize the presence of hydrothermal fluids rising and condensating close to the surface and channelled outside the central hydrothermal system toward the flanks of the edifice, along its slopes.

Based on these surveys, a fluid flow model can be proposed on volcanoes, involving activity of adventive hydrothermal fluid circulations (see Fig. 6). The main hydrothermal system is generally bounded by old structures (NeoStromboli crater boundary in the present case). Water vapour condenses at the top of the edifice near the ground surface. Part of this hydrothermal water contributes to the fluid flow on the flanks of the edifice, through a shallow fluid flow drainage levels. In the case of Stromboli, this shallow level seems to be connected to a deeper one. These two pathways seem to be interconnected in several areas in the upper part of the north-eastern flank. However, one question still needs to be solved to better constrain the general geometric fluid flow model of Stromboli volcano: below $\sim 500 \mathrm{~m}$ a.s.l., we do not know what is the interaction between the central hydrothermal system and the flank fluid flow. Deeper electric resistivity tomography profiles could help to image such an interaction.

Recent geochemical studies of the thermal waters located on the north-eastern coast of Stromboli allowed to identified relevant increase in magmatic dissolved gases, with geochemical characteristics closer to magmatic component than the summit gases, few months before eruption onset or paroxysmal activity (Carapezza et al., 2004; Inguaggiato and Rizzo, 2004; Capasso et al., 2005; Rizzo et al., 2009). It is possible that the shallow hydrothermal contamination coming from the top of the volcano and identified in this study is weak as compared to other contaminants such as the rain water or

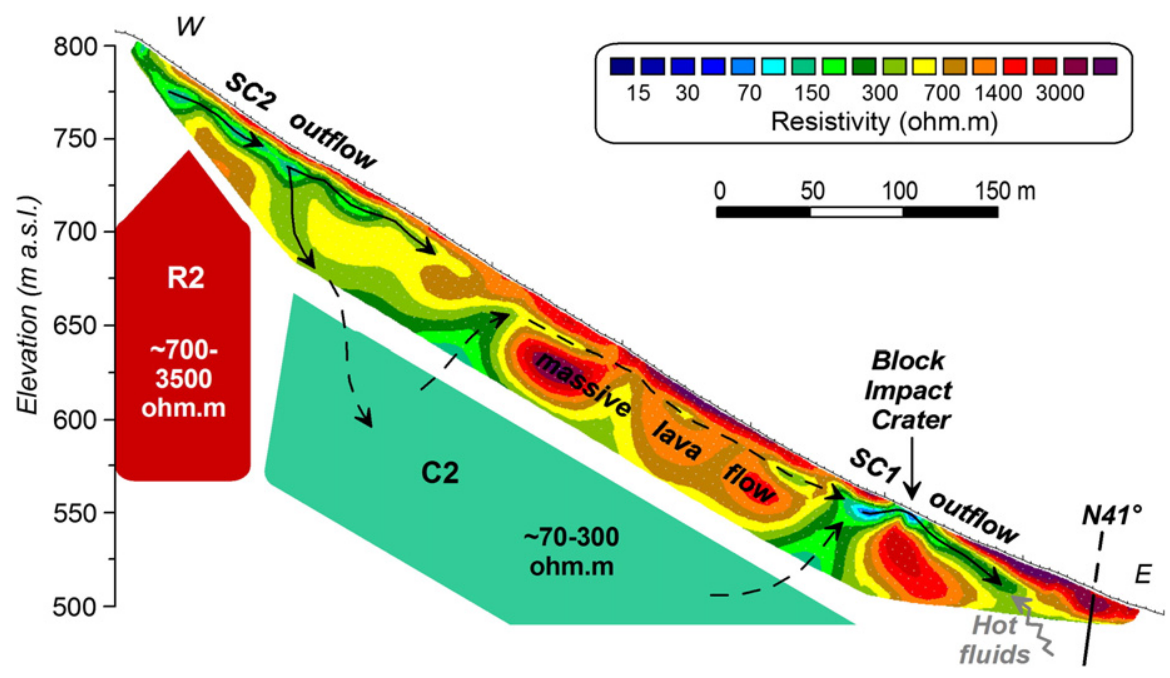

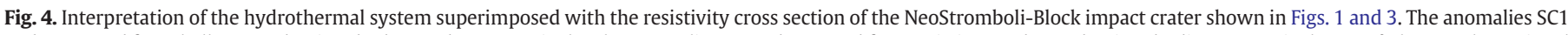

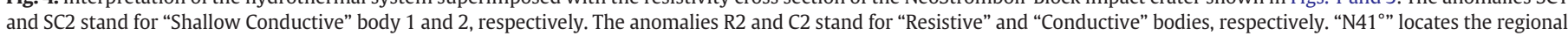
fault crossing the Electrical Resistivity Tomography profile. The arrows indicate the hypothetic fluid flow direction. 

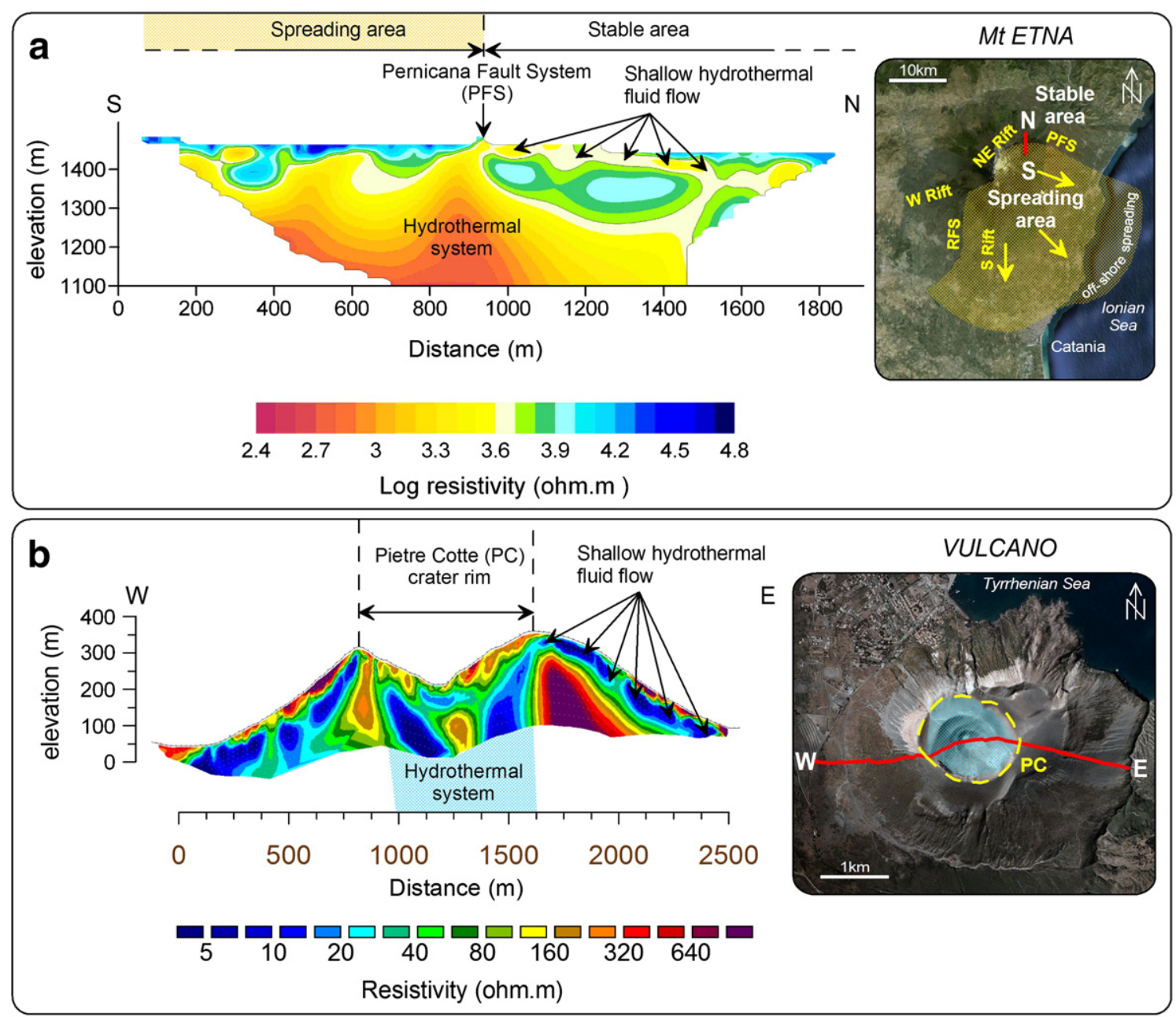

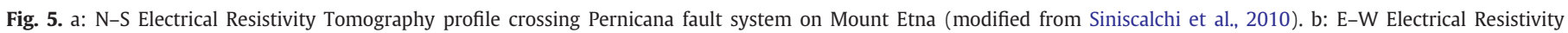
Tomography profile crossing La Fossa cone of Vulcano (modified from Revil et al., 2008).

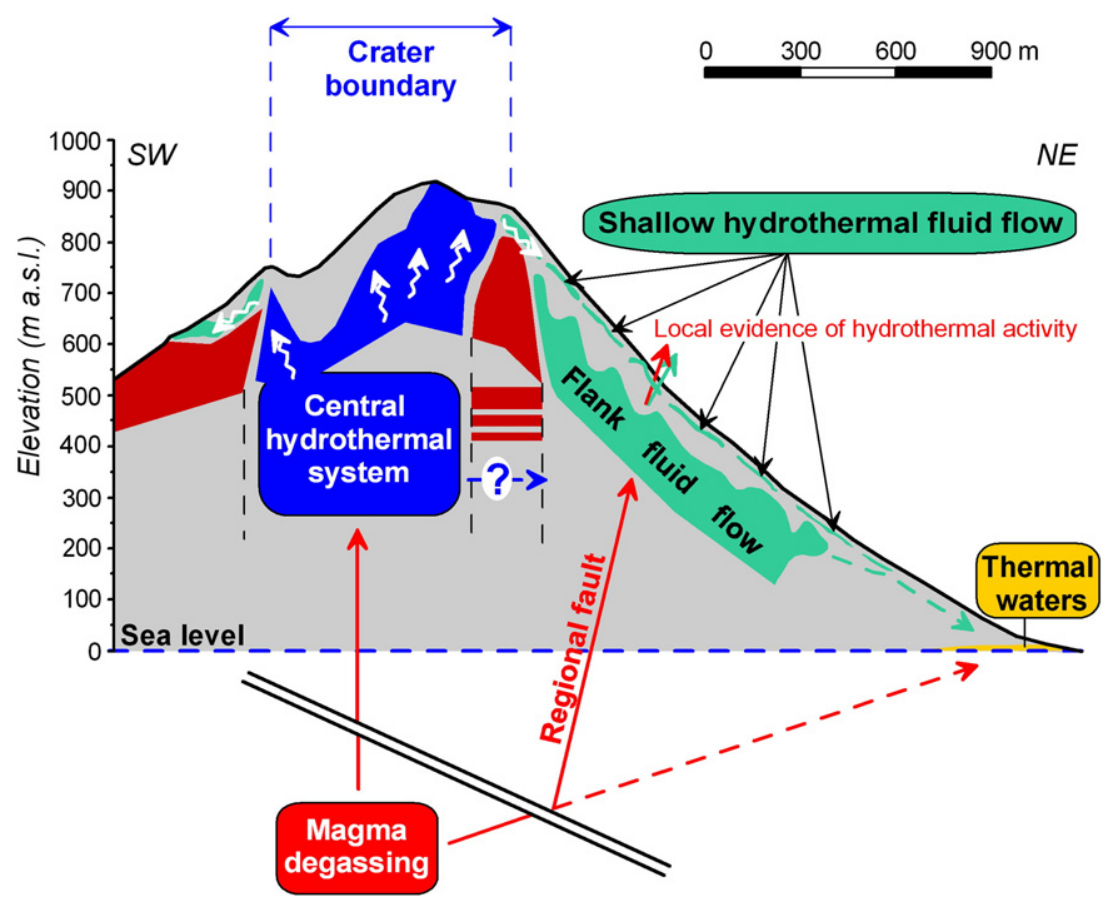

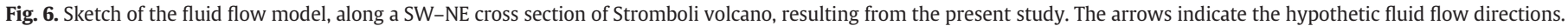


the deep hydrothermal supply along main regional faults. Future gas isotopic surveys from the summit, from the block impact crater and from the coastal thermal waters could help to quantify this contribution but adventive hydrothermal fluid flow should be taken into account to elaborate a general fluid flow model at Stromboli volcano.

\section{Conclusions}

Geophysical and geochemical studies involving DC-resistivity tomography, georadar, self-potential, $\mathrm{CO}_{2}$ soil diffuse degassing, and temperature were performed on the north-eastern flank of Stromboli volcano across a vapour emission area at about $560 \mathrm{~m}$ a.s.l. This anomalous area is a consequence of the impact of a block ejected during the paroxysmal explosion that occurred on Stromboli volcano on March 15th 2007. Our survey evidenced the presence of a shallow hydrothermal level more or less parallel to the topography and located at a depth of about 10-15 m. Locally, this hydrothermal level has been affected by the block impact, which has fractured and increased the soil permeability allowing the hydrothermal fluids to move up to the surface through this small area. The identification of such a shallow hydrothermal level draining hot fluids (up to $76{ }^{\circ} \mathrm{C}$ ) have also been confirmed by a longer resistivity tomography profile crossing the block impact crater. This shallow hydrothermal level receives the contribution of (1) the main hydrothermal system with water condensing shallowly, near the summit area of the volcano, and (2) fluid coming from a deeper source and rising along a regional fault. A relationship was evidenced between this shallow hydrothermal level and the deeper hydrothermal body identified by Finizola et al. (2006). On Etna and Vulcano, similar multidisciplinary studies evidenced the same fluid flow model constituted by a central hydrothermal system feeding the flank fluid flows (Barde Cabusson et al., 2009; Siniscalchi et al., 2010). This model of shallow adventive hydrothermal fluid flow may be a common feature on volcanoes characterized by strong hydrothermal activity and can also contribute to the presence of thermal waters at the base of these volcanic edifices.

\section{Acknowledgements}

The scientific work was possible thanks to the collaboration of many people and is funded through the DPC-INGV Project "V2 PAROXYSM" (agreement 2007-2009) and by the Università Roma Tre, the Laboratoire GéoSciences Réunion, the Dipartimento di Geoscienze Università di Padova, the Laboratorio di Geofisica IMAA-CNR Potenza, and the INGV Palermo. The authors thank Adrien Laborde (AUC Aixen-Provence), Casi Lock, and Zazà for their field assistance, Rocky Chipartou for permanent field encouragement, and Prof. Alberto Godio of the Polytechnic of Turin for the use of his TEM-FAST 48 equipment. This is IPGP contribution n. 2445.

\section{References}

Barberi, F., Rosi, M., Sodi, A., 1993. Volcanic hazard assessment at Stromboli based on review of historical data. Acta Vulcanol. 3, 173-187.

Barberi, F., Civetta, L., Rosi, M., Scandone, R., 2009. Chronology of the 2007 eruption of Stromboli and the activity of the Scientific Synthesis Group. J. Volcanol. Geotherm. Res. 182, 123-130. doi:10.1016/j.jvolgeores.2008.09.019.

Barde-Cabusson, S., Finizola, A., Revil, A., Ricci, T., Piscitelli, S., Rizzo, E., Angeletti, B., Balasco, M., Bennati, L., Byrdina, S., Carzaniga, N., Crespy, A., Di Gangi, F., Morin, J., Perrone, A., Rossi, M., Roulleau, E., Suski, B., Villeneuve, N., 2009. New geological insights and structural control on fluid circulation in La Fossa cone (Vulcano, Aeolian Islands, Italy). J. Volcanol. Geotherm. Res. 185, 231-245. doi:10.1016/j. jvolgeores.2009.06.002.

Bonaccorso, A., Calvari, S., Garfi, G., Lodato, L., Patanè, D., 2003. Dynamics of the December 2002 flank failure and tsunami at Stromboli volcano inferred by volcanological and geophysical observations. Geophys. Res. Lett. 30 (18), 1941. doi:10.1029/2003GL017702.

Calvari, S., Spampinato, L., Lodato, L., Harris, A.J.L., Patrick, M.R., Dehn, J., Burton, M.R., Andronico, D., 2005. Chronology and complex volcanic processes during the 20022003 flank eruption at Stromboli volcano (Italy) reconstructed from direct observations and surveys with a handheld thermal camera. J. Geophys. Res. 110, B02201. doi:10.1029/2004JB003129.

Calvari, S., Spampinato, L., Lodato, L., 2006. The 5 April 2003 vulcanian paroxysmal explosion at Stromboli volcano (Italy) from field observations and thermal data. J. Volcanol. Geotherm. Res. 149, 160-175. doi:10.1016/j.jvolgeores.2005.06.006.

Capasso, G., Carapezza, M.L., Federico, C., Inguaggiato, S., Rizzo, A., 2005. Geochemical monitoring of the 2002-2003 eruption at Stromboli volcano (Italy): precursory changes in the carbon and helium isotopic composition of fumarole gases and thermal waters. Bull. Volcanol. 68, 118-134. doi:10.1007/s00445-005-0427-5.

Carapezza, M.L., Federico, C., 2000. The contribution of fluid geochemistry to the volcano monitoring of Stromboli. J. Volcanol. Geotherm. Res. 95, 227-245.

Carapezza, M.L., Inguaggiato, S., Brusca, L., Longo, M., 2004. Geochemical precursors of the activity of an open-conduit volcano: the Stromboli 2002-2003 eruptive events. Geophys. Res. Lett. 31, L07620. doi:10.1029/2004GL019614.

Carapezza, M.L., Ricci, T., Ranaldi, M., Tarchini, L., 2008. Active degassing structures of Stromboli and variations in diffuse $\mathrm{CO}_{2}$ output related to the volcanic activity. J. Volcanol. Geotherm. Res. doi:10.1016/j.jvolgeores.2008.08.006.

Chiodini, G., Frondini, F., Raco, B., 1996. Diffuse emission of CO2 from the Fossa crater Vulcano Island (Italy). Bull. Volcanol. 58, 41-50.

Corwin, R.F., Hoover, D.B., 1979. The self-potential method in geothermal exploration. Geophysics 44 (2), 226-245.

Finizola, A., Sortino, F., Lénat, J.F., Valenza, M., 2002. Fluid circulation at Stromboli volcano (Aeolian Islands, Italy) from self-potential and CO2 surveys. J. Volcanol. Geotherm. Res. 116, 1-18.

Finizola, A., Sortino, F., Lénat, J.F., Aubert, M., Ripepe, M., Valenza, M., 2003. The summit hydrothermal system of Stromboli. New insights from self-potential, temperature, $\mathrm{CO} 2$ and fumarolic fluid measurements, Structural and monitoring implications. Bull. Volcanol. 65, 486-504. doi:10.1007/s00445-003-0276-z.

Finizola, A., Lénat, J.F., Macedo, O., Ramos, D., Thouret, J.C., Sortino, F., 2004. Fluid circulation and structural discontinuities inside Misti volcano (Peru) inferred from self-potential measurements. J. Volcanol. Geotherm. Res. 135, 343-360. doi:10.1016/j.jvolgeores.2004.03.009.

Finizola, A., Revil, A., Rizzo, E., Piscitelli, S., Ricci, T., Morin, J., Angeletti, B., Mocochain, L., Sortino, F., 2006. Hydrogeological insights at Stromboli volcano (Italy) from geoelectrical, temperature, and $\mathrm{CO}_{2}$ soil degassing investigations. Geophys. Res. Lett. 33, L17304. doi:10.1029/2006GL026842.

Finizola, A., Aubert, M., Revil, A., Schütze, C., Sortino, F., 2009. Importance of structural history in the summit area of Stromboli during the 2002-2003 eruptive crises inferred from temperature, soil $\mathrm{CO}_{2}$, self-potential, and electrical resistivity tomography. J. Volcanol. Geotherm. Res. 183, 213-227. doi:10.1016/j.jvolgeores.2009.04.002.

Gomez-Ortiz, D., Martin-Velazquez, S., Martin-Crespo, T., Marquez, A., Lillo, J., Lopez, I. Carreno, F., 2006. Characterization of volcanic materials using ground penetrating radar: a case study at Teide volcano (Canary Islands, Spain). J. Appl. Geophys. 59 (1), 63-78 ISSN 0926-9851.

Inguaggiato, S., Rizzo, A., 2004. Dissolved helium isotope ratios in ground-waters: a new technique based on gas-water re-equilibration and its application to Strombol volcanic system. Appl. Geochem. 19, 665-673. doi:10.1016/j.apgeochem.2003.10.009.

Loke, M.H., Barker, R.D., 1996. Rapid least-squares inversion of apparent resistivity pseudosections by a quasi-Newton method. Geophys. Prospect. 44, 131-152.

Lorne, B., Perrier, F., Avouac, J.P., 1999a. Streaming potential measurements, 1, Properties of the electrical double layer from crushed rock samples. J .Geophys. Res. 104, 17,857-17,877.

Lorne, B., Perrier, F., Avouac, J.P., 1999b. Streaming potential measurements, 2, Relationship between electrical and hydraulic flow patterns from rock samples during deformation. J. Geophys. Res. 104, 17,879-17,896.

Marsella, M., Proietti, C., Sonnessa, A., Coltelli, M., Tommasi, P., Bernardo, E., 2009. The evolution of the Sciara del Fuoco subaerial slope during the 2007 Strombol eruption: relation between deformation processes and effusive activity. J. Volcanol. Geotherm. Res. doi:10.1016/j.jvolgeores.2009.02.002.

Neri, M., Lanzafame, G., 2008. Structural features of the 2007 Stromboli eruption. J. Volcanol. Geotherm. Res. doi:10.1016/j.jvolgeores.2008.07.021.

Patanè, D., Mattia, M., Di Grazia, G., Cannavò, F., Giampiccolo, E., Musumeci, C. Montalto, P., Boschi, E., 2007. Insights into the dynamic processes of the 2007 Stromboli eruption and possible meteorological influences on the magmatic system. Geophys. Res. Lett. 34, L22309. doi:10.1029/2007GL031730.

Pettinelli, E., Beaubien, S.E., Lombardi, S., Annan, A.P., 2008. GPR, TDR, and geochemistry measurements above an active gas vent to study near-surface gas-migration pathways. Geophysics 73 (A11). doi:10.1190/1.2815991.

Pribnow, D.F.C., Schütze, C., Hurter, S.J., Flechsig, C., Sass, J.H., 2003. Fluid flow in the resurgent dome of Long Valley Caldera: implications from thermal data and deep electrical sounding. J. Volcanol. Geotherm. Res. 127, 329-345.

Revil, A., Pezard, P.A., Glover, P.W.J., 1999a. Streaming potential in porous media. 1. Theory of the zeta potential. J. Geophys. Res. 104, 20,021-20,031.

Revil, A., Schwaeger, H., Cathles, L.M., Manhardt, P.D., 1999b. Streaming potential in porous media. 2. Theory and application to geothermal systems. J. Geophys. Res. 104, 20,033-20,048.

Revil, A., Leroy, P., 2001. Hydroelectric coupling in a clayey material. Geophys. Res. Lett. $28,1643-1646$.

Revil, A., Finizola, A., Sortino, F., Ripepe, M., 2004. Geophysical investigations at Stromboli volcano, Italy: implications for ground water flow and paroxysmal activity. Geophys. J. Int. 157, 426-440. doi:10.1111/j.1365-246X.2004.02181.x.

Revil, A., Finizola, A., Piscitelli, S., Rizzo, E., Ricci, T., Crespy, A., Angeletti, B., Balasco, M., Barde, Cabusson S., Bennati, L., Bolève, A., Byrdina, S., Carzaniga, N., Di Gangi, F., Morin, J., Perrone, A., Rossi, M., Roulleau, E., Suski, B., 2008. Inner structure of La Fossa di Vulcano (Vulcano Island, southern Tyrrhenian Sea, Italy) revealed by high-resolution electric resistivity tomography coupled with self-potential, 
temperature, and $\mathrm{CO}_{2}$ diffuse degassing measurements. J. Geophys. Res. 113, B07207. doi:10.1029/2007JB005394.

Rizzo, A., Grassa, F., Inguaggiato, S., Liotta, M., Longo, M., Madonia, P., Brusca, L., Capasso, G. Morici, S., Rouwet, D., Vita, F., 2009. Geochemical evaluation of observed changes in volcanic activity during the 2007 eruption at Stromboli (Italy). J. Volcanol. Geotherm. Res. 182, 246-254. doi:10.1016/j.jvolgeores.2008.08.004.

Rosi, M., Bertagnini, A., Landi, P., 2000. Onset of the persistent activity at Stromboli volcano (Italy). Bull. Volcanol. 62, 294-300.
Russell, J.K., Stasiuk, M.V., 1997. Characterization of volcanic deposits with groundpenetrating radar. Bull. Volcanol. 58, 515-527.

Siniscalchi, A., Tripaldi, S., Neri, M., Giammanco, S., Piscitelli, S., Balasco, M., Behncke, B., Magrì, C. Naudet, V., Rizzo, E. 2010. Insights into fluid circulation across the Pernicana Fault (Mt. Etna, Italy) and implications for flank instability. J. Volcanol. Geotherm. Res. 193, 137-142. doi:10.1016/j.jvolgeores.2010.03.013. 